\title{
Knowledge of modern contraceptives among undergraduate students of College of Health Sciences of Usmanu Danfodiyo University Sokoto, Nigeria
}

\author{
Ahmad Maryam Muhammad ${ }^{1 *}$, Adamu Habibullah², Ismail Ahmad Muhammad², Auwalu \\ Muhammed $^{1}$, Usman Nasir Nakakana ${ }^{3}$, Hindatu Tukur Muhammad ${ }^{4}$
}

\begin{abstract}
${ }^{1}$ Department of Nursing Sciences, ${ }^{2}$ Department of Community Medicine, ${ }^{3}$ Department of Peadiatric, ${ }^{4}$ Department of Family Medicine, College of Health Sciences, Usmanu Danfodiyo University Sokoto, Nigeria
\end{abstract}

Received: 10 April 2018

Revised: 02 May 2018

Accepted: 05 May 2018

*Correspondence:

Dr. Ahmad Maryam Muhammad,

E-mail: maryam.ahmed360@gmail.com

Copyright: (C) the author(s), publisher and licensee Medip Academy. This is an open-access article distributed under the terms of the Creative Commons Attribution Non-Commercial License, which permits unrestricted non-commercial use, distribution, and reproduction in any medium, provided the original work is properly cited.

\begin{abstract}
Background: Many undergraduate students in Nigerian Universities are at increased risk of sexually transmitted infections, unwanted pregnancies with resultant illegal abortions. The aim of this study is to assess the undergraduate students' knowledge of contraceptives. Understanding the knowledge of contraception among students is essential in tackling unwanted pregnancies among youths.

Methods: The researchers use cross-sectional survey, a quantitative approach to the stated objective. About fifty five (55) female students aged 18 to 21 years were enrolled in the study using purposive sampling technique. The instrument for data collection was a structured questionnaire. The fifty-five (55) completed questionnaires were retrieved and data analyzed using SPSS version 20.

Results: The result showed that current overall contraception knowledge was low, while general contraceptive knowledge is high among the student. However, the knowledge of both short-term and long term acting contraceptive methods were very low as reported by the respondents.

Conclusions: This study has implication for health education especially on the use of modern contraceptives. Thus, recommendations were highlighted to improve students' knowledge of the various contraceptive methods.
\end{abstract}

Keywords: Family planning, Knowledge, Modern contraceptive, Undergraduate students

\section{INTRODUCTION}

Contraception has become a generally debated issue around the globe. The term Contraception refers to as the deliberate prevention of pregnancy by using several methods such as; barrier methods, condom act as dual methods of preventing pregnancy and also prevention of sexually transmitted infections (STIs) and HIV., Globally, the population today stands at over 7.3 billion, about 178.5 million of which is the Nigerian population. ${ }^{3}$ Uncontrolled population growth alone is documented as most significant impediment to national development. In
2014, the total fertility per woman around the world was 2.5 children while Nigeria has the fertility rate of about 5.6 per woman. ${ }^{3}$

In the developed world like European and American, it was reported that the women have increased knowledge of contraception with approximately $98 \%$ prefer using the contraceptive pill. ${ }^{4}$ Similarly, in Ghana about $98 \%$ of women and $99 \%$ of men had knowledge of at least one method of contraception..$^{5}$ Thus, globally, the knowledge of contraception including modern contraception is increasing particularly among adolescents and young 
adults. However, a study conducted in Nigeria, shows a gap in knowledge of contraceptives for the purpose of prevention of unintended pregnancies among college students aged 19 to 24 years. ${ }^{6}$ Similarly, a study reveals that young women in developing countries have insufficient knowledge on contraceptives and are not well educated on complications associated with pregnancy. ${ }^{7}$

Globally, there are averages of 87 million unintended pregnancies each year; a large proportion of which are among teenagers. ${ }^{8}$ Estimates show that about 222 million women in developing countries had an unmet need for a modern contraceptive method as at $2012 .{ }^{9}$ The knowledge of contraception remains a significant problem in the society as many unplanned pregnancies have been reported every year. The Nigeria's National Demographic Health Survey classified modern contraceptive methods to include; oral pills, injectables, female condom, male condoms, implants, intra-uterine device (IUD), male sterilization, female sterilization, diaphragm, emergency contraceptive, lactation amenorrhoea and jelly/foam. ${ }^{10}$ Even though, most of the students require comprehensive understanding of these contraceptive methods. Nigerian students have relatively increased in contraceptives knowledge which was estimated to be $50.7 \%$ out of which $57.6 \%$ do not have the knowledge about how it works. ${ }^{11}$ On the short term contraceptives, a study conducted among high school students in rural southern Nigeria shows that the most commonly known short-term contraceptives method were injectables $59.5 \%$, condoms $42.2 \%$ POP $39.2 \%$ and Oral contraceptive pills $34.0 \%$, while $60 \%$ of the sample size have no knowledge of emergency contraceptive and the appropriate contraceptive that can be used as emergency contraceptive. $^{12}$

In conclusion, there is evidence that knowledge of contraceptives, especially emergency contraceptive is deficient among Nigerian youth including undergraduate students. It was also observed that knowledge of how contraceptives works among undergraduate student has not been well examined previously.

\section{METHODS}

In this study, a quantitative, descriptive (cross-sectional survey) is employed. This approach is considered a quick technique that allows the researcher to describe the knowledge of various contraceptive methods among the study population.

\section{Population and sample}

The population of study were female undergraduate students located in college of health sciences of Usmanu Danfodiyo University Sokoto. There was no access to sampling frame to determine the total number of student during the study. Thus, sample size and techniques were based on non-probability method (purposive). A total of 55 student participated in the study.

\section{Instrument for data collection}

A self-administered structured questionnaire was specifically designed for this study. The author's choice to choose of terms used in the questionnaire was informed by the research problem statement.

The first part of the questionnaire sought to elicit information on the socio-demographic data from the respondents. The second part covers the participant's knowledge on general knowledge of contraception. The third part covers the study participant's knowledge on short term contraceptive methods, while the fourth part section assesses the study participant's knowledge on Long Acting Reversible contraceptive methods.

The Validity of the instrument was checked by the supervisory committee to ensure the questions reflect the ideas on modern contraceptive. A pretest of the instrument with 12 respondent shows an overall reliability index (Cronbach's alpha) of 0.72 for the knowledge items.

\section{Data collection}

The primary investigator obtained permission from the dean and heads of department. At the end of the student lectures, the researcher will have met with the students in order to present the aim of the research, gained consent for participation and those who volunteered were asked to complete the questionnaire. Few department have only year one and two student, and some student were out for clinical posting. In addition, some of the students that are around and within the age bracket of the study were reluctant in filling the questionnaire which result to the few (55) number of questionnaire filled. The period for data collection was 2 weeks when a significant number of students are present in the college of health sciences of UDUS.

\section{Statistical analysis}

The data obtained from the filled questionnaires coded and entered into a database. Logical checks were conducted to check for consistency and validity of the data and frequencies was calculated using SPSS software version 21 (Chicago, IL). Thus, data was analysed using descriptive statistic.

\section{RESULTS}

\section{Socio-demography of respondents}

Their mean age was $19.87 \pm 1.08$ (age range was 18 to 21 years) with the majority of the respondent ages 20-21 years $(67.2 \%)$. Majority of the respondents were single $51(92.7 \%)$, and $46(83.6 \%)$ of the respondents were Muslim which represents more than two third of the study participants (Table 1). 
Table 1: Socio-demographic characteristics of respondents.

\begin{tabular}{|c|c|c|}
\hline Variables & Frequency & Percentage \\
\hline \multicolumn{3}{|l|}{ Age of the respondents } \\
\hline 18 years & 9 & 16.4 \\
\hline 19 years & 9 & 16.4 \\
\hline 20 years & 17 & 30.8 \\
\hline 21 years & 20 & 36.4 \\
\hline \multicolumn{3}{|l|}{ Total $=55$} \\
\hline \multicolumn{3}{|l|}{ Mean $=19.8727 \pm 1.08$} \\
\hline \multicolumn{3}{|l|}{ Marital status } \\
\hline Single & 51 & 92.7 \\
\hline Married & 3 & 5.5 \\
\hline In a committed relationship & 1 & 1.8 \\
\hline \multicolumn{3}{|l|}{ Total $=55$} \\
\hline \multicolumn{3}{|l|}{ Religion } \\
\hline Christianity & 9 & 16.4 \\
\hline Islam & 46 & 83.6 \\
\hline Others & 0 & 0.0 \\
\hline Total $=55$ & & \\
\hline
\end{tabular}

\section{General knowledge of contraceptive}

The result of general knowledge of contraceptive is presented in Table 2 with response rate for each knowledge item. The mean knowledge score of the respondents that took part in the study was $74.55 \pm 26.57$, with the majority representing $51(92.7 \%)$ of the participant demonstrating good knowledge that contraceptive is for the prevention of pregnancy. Meanwhile, $38(74.5 \%)$ of the respondents were knowledgeable about the general uses of contraceptives. While, $42(82.4 \%)$ of the respondents demonstrated good knowledge that condom has dual function (prevention of conception and sexually transmitted diseases.

Table 2: General knowledge of contraceptive among respondents.

\begin{tabular}{|c|c|c|c|}
\hline Items (questions) & $\begin{array}{l}\% \\
\text { correct } \\
\text { answer }\end{array}$ & $\begin{array}{l}\% \\
\text { wrong } \\
\text { answer }\end{array}$ & $\begin{array}{l}\text { Response } \\
\text { rate }\end{array}$ \\
\hline $\begin{array}{l}\text { Meaning of } \\
\text { contraceptive }\end{array}$ & $\begin{array}{l}52 \\
(96.4 \%)\end{array}$ & $\begin{array}{l}2 \\
(3.8 \%)\end{array}$ & $\begin{array}{l}52 \\
(96.4 \%)\end{array}$ \\
\hline $\begin{array}{l}\text { Uses of } \\
\text { contraceptives }\end{array}$ & $\begin{array}{l}38 \\
(74.5 \%)\end{array}$ & $\begin{array}{l}13 \\
(25.5)\end{array}$ & $51(92.7 \%)$ \\
\hline $\begin{array}{l}\text { Contraceptive } \\
\text { method that can } \\
\text { prevent pregnancy } \\
\text { and sexually } \\
\text { transmitted infection }\end{array}$ & $\begin{array}{l}42 \\
(82.4 \%)\end{array}$ & $\begin{array}{l}9 \\
(17.7 \%)\end{array}$ & $\begin{array}{l}51 \\
(92.7 \%)\end{array}$ \\
\hline
\end{tabular}

\section{Knowledge of short-term acting contraceptives}

Table 3 present the respondent knowledge of short-term acting contraceptives. The mean knowledge score of the respondents was $23.33 \pm 21.89$, and majority $43(78.2 \%)$ of the respondents demonstrated poor knowledge. While most respondents $29(82.9 \%)$ demonstrated good knowledge of the constituent of combined oral contraceptives (COC; Progestogen and Estrogen), only $16(45.7 \%)$ are aware of its mode of action. Also, only 20 $(36.4 \%)$ of respondents have the knowledge of the side effect of COC (irregular menstrual pattern). Furthermore, the median time of returning to fertility after COC is unknown to most respondents $23(92.0 \%)$. Finally, more than half $14(58.3 \%)$ of the respondents have poor knowledge of the interval for administration of DepoProvera.

Table 3: Respondents' knowledge of short-term acting contraceptives.

\begin{tabular}{|c|c|c|c|}
\hline Items (questions) & $\begin{array}{l}\% \\
\text { correct } \\
\text { answer }\end{array}$ & $\begin{array}{l}\% \\
\text { wrong } \\
\text { answer }\end{array}$ & $\begin{array}{l}\text { Response } \\
\text { rate }\end{array}$ \\
\hline $\begin{array}{l}\text { Constituents of } \\
\text { combined oral } \\
\text { contraceptive (COC) }\end{array}$ & $\begin{array}{l}29 \\
(82.9 \%)\end{array}$ & $\begin{array}{l}5 \\
(17.2 \%)\end{array}$ & $\begin{array}{l}35 \\
(63.6 \%)\end{array}$ \\
\hline $\begin{array}{l}\text { The mechanism of } \\
\text { action of COC }\end{array}$ & $\begin{array}{l}16 \\
(45.7 \%)\end{array}$ & $\begin{array}{l}19 \\
(54.3 \%)\end{array}$ & $\begin{array}{l}35(63.6 \\
\%)\end{array}$ \\
\hline $\begin{array}{l}\text { Common side effect } \\
\text { of COC }\end{array}$ & $\begin{array}{l}20 \\
(36.4 \%)\end{array}$ & $\begin{array}{l}12 \\
(21.8 \%)\end{array}$ & $\begin{array}{l}32 \\
(58.2 \%)\end{array}$ \\
\hline $\begin{array}{l}\text { Median time for } \\
\text { fertility return after } \\
\text { stopping COC }\end{array}$ & $2(8.0 \%)$ & $\begin{array}{l}23 \\
(92.0 \%)\end{array}$ & $\begin{array}{l}25 \\
(45.5 \%)\end{array}$ \\
\hline $\begin{array}{l}\text { Interval for given } \\
\text { Depo-Provera }\end{array}$ & $\begin{array}{l}10 \\
(41.7 \%)\end{array}$ & $\begin{array}{l}14 \\
(58.3 \%)\end{array}$ & $\begin{array}{l}24 \\
(43.6 \%)\end{array}$ \\
\hline
\end{tabular}

\section{Knowledge of long acting reversible contraceptive}

The respondents' knowledge of long acting reversible contraceptive (LARC)) is presented in Table 4.

Table 4: Respondents' knowledge of long acting reversible contraceptive.

$\left.\begin{array}{|llll|}\hline \begin{array}{l}\text { Items } \\ \text { (questions) }\end{array} & \begin{array}{l}\text { \% correct } \\ \text { answer }\end{array} & \begin{array}{l}\text { \% wrong } \\ \text { answer }\end{array} & \begin{array}{l}\text { Response } \\ \text { rate }\end{array} \\ \begin{array}{l}\text { Return to } \\ \text { fertility after }\end{array} & \begin{array}{l}5 \\ \text { LARC }\end{array} & \begin{array}{l}19 \\ (79.2 \%)\end{array} & \begin{array}{l}24 \\ (43.6 \%)\end{array} \\ \hline \begin{array}{l}\text { Place where } \\ \text { LARC are } \\ \text { provided }\end{array} & 19 & 7 & 26 \\ \begin{array}{l}\text { An example of } \\ \text { LARC }\end{array} & 8 & (26.9 \%) & (47.3 \%)\end{array}\right)$

Although a significant number did not respond to the questions, the mean knowledge score of the respondents was $18.18 \pm 23.81$, and majority of them $48(87.3 \%)$ had demonstrated poor knowledge of LARC. The knowledge 
of respondents on the return of fertility after stopping LARC was poor for, 19 (79.2\%) respondents, and 19 out of $26(73.1 \%)$ are aware that LARC is provided in the health facility. Only $8(30.8 \%)$ were able to identify an example of LARC. In addition, the route of insertion of Intrauterine device (IUD) and duration of action Implanon was unknown in $20(68.9 \%)$ and $12(66.7 \%)$ of the respondents respectively.

\section{Sources of information on contraceptives}

The sources of information on contraceptives are described in Figure 1. Most respondent 21 (40.0\%) obtain information on contraceptives from other unspecified sources, while $13(25.0 \%)$ received information from social media. Equal number of respondents reported to have information from parents and peer groups $9(17.3 \%)$ each.

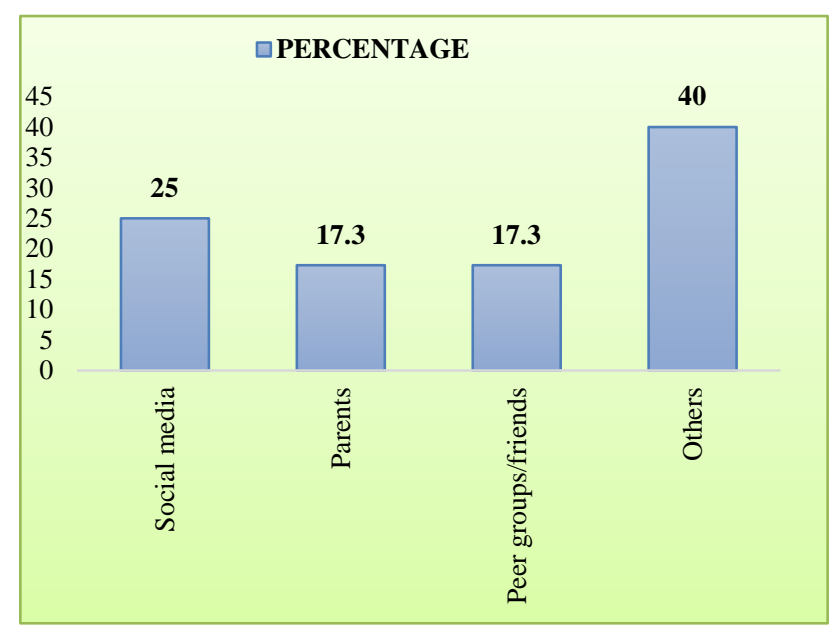

Figure 1: Respondents source of information.

\section{DISCUSSION}

Most respondents are within their youthful age, single in relationship, and mostly Muslims. The finding is not surprising wince the study was conducted among undergraduate student of age 18-21 years in northern Nigeria, were the dominant religion is Islam.

Majority have a good general knowledge of contraceptive methods. This study shows that general knowledge of contraception among female students of UDUS was as high. Findings are in line with the findings from Ekine, which shows that general contraception knowledge among University students in Africa was approaching $100 \% .{ }^{13}$ This is in contrast to studies conducted in Nigeria, which revealed that contraceptive knowledge was as low as $41 \%$ to $63 \%$ among Nigerians depending on the geographical region of the study, and also a study in South- south Nigeria revealed lower level of contraceptive knowledge among high school students. ${ }^{14,15}$

Majority of the respondent demonstrated poor knowledge of short-term acting contraceptives. Findings in this study is congruent with the study among high school students in southern Nigeria. ${ }^{12}$ In contrast with other Nigerian Studies that revealed high level of short-term contraceptive methods knowledge among those participants. ${ }^{10,16,17}$ It is expected that students from the University should be more exposed than the high school students, but in Nigeria, undergraduate's exposure from the northern part of the country can be compared with students of high school from southern part. This could be as a result of religious practices, socio-cultural differences among others.

Most respondents demonstrated poor knowledge of long acting reversible contraceptives. Finding is similar to the study in Nigeria, which shows low level of LARC methods knowledge among Nigerian women of age 1549 years. $^{18}$ In contrast, in a study among adolescent females of secondary institution revealed that knowledge of LARC methods among youths in southern Nigeria is high. ${ }^{16}$ This could be as a result of high level of education, level of socialization and contraceptive awareness in southern part of Nigeria to compare with the northern part. The low knowledge of participants from this study could be that those women are from country side and not educated. But the participants that took part in this study are educated people but yet demonstrated poor knowledge of LARC.

The main sources of information are other unspecified sources. This study is in contrast to other Nigerian studies, which suggest that the social media is the major source of information on contraception by Nigeria youth. ${ }^{6,11,19}$ Other sources of information which was not specified in the data collection tool are likely not to be the best source of information, since one source of accurate information is through the health care workers which are a difficult way of getting information because it is not adolescent or young women friendly as argued by Abiodun and Balogu. ${ }^{6}$ This unfriendliness is as a result of cultural practices in Nigeria, where family planning services are still regarded by many as preserve for married people only. ${ }^{6,20}$ This could account for low contraception knowledge among the study participants. Information about contraception from peer groups/friends accounts for only $17.3 \%$ of this study which is low. It was argued that knowledge of contraception, which students usually get and rely on from Peer groups/friends could be incomplete or false. ${ }^{21}$ This exposes the students to risk of unintended pregnancy and contraction of STIs due to incorrect use of contraception as a result inadequate knowledge gotten from friends. Information between parents and their children with regards to contraception among these study participants was low.

Naturally, it is belief in the society that, parents by virtue of their experience in life should be responsible for providing their children with adequate and information about reproductive health and contraception. However, most Nigerian parents failed to do that, this is either because of their traditional or religious beliefs or personal 
reasons. Traditionally, discussions around issues regarding contraception and sex are not encourage between older members and youths that are unmarried of the society, it is considered as immoral, inappropriate and not acceptable, even with health workers. As was also found in Abiodun and Balogu, this makes it difficult for parent to admit that adolescents are sexuality active with believe that information about sexual behaviours should not be discussed freely with adolescents because discussing contraception with them may promote sexuality. ${ }^{6,22}$ As a result, adolescents do not have adequate knowledge of complications of sexual behaviour until they become pregnant and or infected with STIs.

The main limitation of this study is the limited the number of respondents because most of the students were on brake during the limited time of the study. In addition, the sampling techniques used was a non-probability method which may affect generalization of findings to study population. Thus, the use of large sample size and probability sampling techniques will enable genralization of findings in future researches.

\section{CONCLUSION}

The great potential of contraceptive methods to prevent unwanted pregnancies is far from being realized in Nigeria. University students would be expected to have greater knowledge of contraception.

Therefore, the study was carried out to ascertain the knowledge level of contraception among female students (18 to 20 years) of college of health sciences of UDUS, northern Nigeria.

The study revealed a high level of general contraception knowledge and low level of LARC and short-term contraceptive methods knowledge. The overall knowledge was low with less than $50 \%$ score.

\section{Recommendations}

Firstly, the need for various intervention is required for contraception knowledge to be increased among university students, which may reduce risk associated with unintended pregnancy and early motherhood, among female students more especially the northern region.

Secondly, with regards to the low level of contraceptive knowledge among the students, there is a need to improve the knowledge of contraception among students. Accurate and comprehensive information with regards to reproductive health and contraception should be passed to students through educational programmes.

In other to achieve this, parents/guardians need to be encouraged through educational programmes organised by either the governments, religious organizations, nongovernmental organizations, public education programme organised by relevant authorities, using the media, and even community leaders

The cultural beliefs that discourage dissemination of contraceptives information among youths should be changed to the minimal and rather encourage a friendly relationship between parents/guardians and children, adults and youths. These mutual relationships could help in passing accurate information with regards to reproductive health and contraception since the relationship is built based on trust. Lastly, health care providers should be encouraged on friendliness to students that are seeking for contraceptives method and provide them with sound information on uses, side effect and how it works in terms of prevention against unwanted pregnancies and STIs.

With regards to the study sample size, in further studies large sample size should be used form different institutions in northern Nigeria so as to be able to making generalizations based on the findings of the study.

\section{ACKNOWLEDGMENTS}

The researchers want to thank the administration the college of health sciences for the interest and support given in the conduct of the study.

Funding: No funding sources

Conflict of interest: None declared

Ethical approval: Not required

\section{REFERENCES}

1. Obinna C. Birth Control: The Plan Every Family Needs. V. Nigerian News, 2011. Available at http://vanguardngr.com/2011/06/birth-control-theplan-every-family-needs Accessed June, 11th 2015.

2. Olugbenga-Bello AI, Abodunrin OL, Adeomi AA. Contraceptive practices among women in rural communities in South-Western Nigeria. Glob J Med Res. 2011;11(2):1-8.

3. Walke R. Demographic Vulnerability Report: Where Population Growth Poses the Greatest Challenges, Washington, DC: Population Institute; 2015.

4. Johnson S, Pion C, Jennings V. Current methods and attitudes of women towards contraception in Europe and America. Reprod Health. 2013;10(7):1-9.

5. Asamoah B, Agardh A, Ostergren P. Inequality in fertility rate and modern contraceptive use among Ghanaian women from 1988-2008. Int J Equity Health. 2013;12(37):1-12.

6. Abiodun O, Balogun R. Sexual activities and contraceptives use among young female students of tertiary education Instuitutions in Ilorin, Nigeria. Contraception. 2009;79:146-9.

7. Williamson ML, Buston K, Sweeting H. Young women's perceptions of pregnancy risk and use of emergency contraception. Contraception. 2009;79(4):310-5. 
8. Bellizzi S, Sobel HL, Obara H, Temmerman M. Underuse of modern methods of contraception: underlying causes and consequent undesired pregnancies in 35 low-and middle-income countries. Human Reproduction. 2015 Feb 3;30(4):973-86.

9. Peterson HB, Darmstadt GL, Bongaarts J. Meeting the unmet need for family planning: now is the time. The Lancet. 2013 May 18;381(9879):1696-9.

10. National Demographic and Health Survey. National Population Commission Federal Republic of Nigeria Abuja, Nigeria, Calverton, Maryland: ICF Macro;2008.

11. Akani CI, Enyindah CE, Babatunde S. Emergency contraception: knowledge and perception of female undergraduates in the Niger Delta of Nigeria. Ghana Med J. 2008;42(2):69-70.

12. Omo-Aghoja LO, Omo-Aghoja VW, Aghoja CO, Okonofua FE, Aghedo O, Umueri C, et al. Factors associated with the knowledge, practice and perceptions of contraception in rural southern Nigeria. Ghana Med J. 2009;43(3):115-21.

13. Ekine AA, West OL, Ibrahim IA, Ikeanyi E. Prospective study of the knowledge, awareness and practice of effective contraceptive method among Secondary and Higher Institution Students in Rivers and Bayelsa States of Nigeria. IOSR J Dent Med Sci. 2015;14(2Ver. V):62-70.

14. Owonikoko KM, Bello-Ajao HT, Fawole AA, Adeniji AO. Determinants of sexual activities and contraceptive usage among adolescents in high schools in Ogbomoso, a semi-urban settlement in Nigeria. Int J Adoles Med Health. 2015;1(22):1-35.

15. Duru C, Nnebue CC, Uwakwe KA, Obi-Okaro AC, Diwe KC, Chineke HN et al. Sexual behaviours and contraceptive use among female secondary school adolescents in a rural town in Rivers state, Southsouth Nigeria. Niger J Med. 2015;24(1):17-27.

16. Eke AC, Alabi-Isama L. Long-acting reversible contraception (LARC) use among adolescent females in secondary institutions in Nnewi, Nigeria. J Obstet Gynaecol. 2011 Feb 1;31(2):164-8.

17. Salako AA, Iyaniwura CA, Jeminusi OA, Sofowora R. Sexual behaviour: Contraception and fertility among in-school adolescent in Ikenne local government, South-western Nigeria. Nigerian J Clin Pract. 2006;9(1):26-36.

18. National Demographic and Health Survey. National Population Commission Federal Republic of Nigeria Abuja, Nigeria, Rockville, Maryland: ICF International;2013.

19. Tayo A, Oluwarotimi A, Abiola B, Adeniyi A, Dele $\mathrm{O}$, Lukeman S. Contraceptive knowledge and usage amongst female secondary school students in Lagos, Southwest Nigeria. Public Health Epidemiol. 2011;3(1):34-7.

20. Otoide VO, Oronsaye F, Okonofua FE. Why Nigerian adolescents seek abortion rather than contraception: evidence from focus-group discussions. Int Fam Plann Perspect. 2001 Jun 1:7781.

21. Puharić D, Borovac JA, Petrov B. Attitudes of adolescents towards sexual health in three cities from Croatia and Bosnia and Herzegovina. Int Nurs Rev. 2015 Sep 1;62(3):294-302.

22. Sugh ET. The challenges of teaching sexual education to Nigerian adolescents and its Implication in the 21st Century. Nigerian J Health Ed. 2011;15(1):1-10.

Cite this article as: Muhammad AM, Habibullah A, Muhammad IA, Muhammed A, Nakakana UN, Muhammad HT. Knowledge of modern contraceptives among undergraduate students of College of Health Sciences of Usmanu Danfodiyo University Sokoto, Nigeria. Int J Reprod Contracept Obstet Gynecol 2018;7:2100-5. 